\title{
Integration of Certification and Performance Management of Physical Education Teachers
}

\author{
Syahruddin \\ Universitas Negeri Makassar \\ Makassar, Indonesia
}

\author{
Tri Sudirga \\ SD Negeri 6 Cikere \\ Pangkep, Indonesia
}

\author{
Muhammad Syahrul Saleh \\ M. Sahib Saleh \\ Universitas Negeri Makassar Universitas Negeri Makassar \\ Makassar, Indonesia Makassar, Indonesia
}

\begin{abstract}
The aim this research is examining the management of "certified teacher" performance in planning, implementing, and evaluating the learning process of physical education at a primary school in Makassar. The data were collected from the headmaster, the certified physical education teachers, their colleagues, students, and other documents. The data were collected through interview, observation, and documentation. Results revealed that the lesson plan of physical education teachers had been conducted well showed by the arrangement of learning package, formulation of learning adjective, formulation of subject materials, determining learning method, determining media/teaching aids, formulation of assessment and time allocation. The implementation of physical education lesson had not been maximized yet indicated by the way to start the lesson that the teacher did not do apperception well. For example, stimulated learners to recall previous material and did not explain the purpose of learning as well as did not summarize the lesson at the end of the lesson, and also did not provide any feedback. Learning evaluation had not maximized yet because the teachers did not make and follow-up the program.
\end{abstract}

Keywords-certified; performance management; physical education

\section{INTRODUCTION}

Teachers should be better prepared mentally to face globalization. Special teachers of Physical Education (PE) should develop their capability to improve performance management who are expected to bring achievement enhance the quality of education in the school community and outside the school. PE teachers are teachers who apply the values of sportsmanship, professional, disciplined, and socially deviant to address problems in the community.

PE teachers in Makassar have largely followed the certification, either through portfolio or Professional Teacher Education and Training (PLPG). Based on data from the initial observation of 2014 teacher certification participants PE Makassar City Elementary School number 27 and pass 13, the remaining 14 did not pass a variety of reasons. For teachers who pass the certification has various methods for enhancing the professionalism they have. The performance indicators that they had also vary in the learning process It is influenced by educational background, social and insights different [1].
The question is to what extent the teacher certification program as an effective instrument in improving the quality of education related to the development of performance management of teachers? Is there any guarantee that in the field, PE teachers who have passed the certification automatically have become truly professional teachers in carrying out their duties?. Thus, it can be seen how well the performance management of the teachers who have been certified. This study aims to determine the condition of PE teachers who have been certified, and specifically to describe the condition of performance management of teachers who have been PE certified and to understand the performance management of PE teachers in learning, planning, implementing, and evaluating of their learning and assessment of learning outcomes?

\section{RESEARCH METHOD}

This study uses qualitative research methods which analyze the problems that are not yet clear, holistic, complex, dynamic and full of meaning that could not have data on the situation of the social situation in the nets with quantitative methods with instruments such as tests, questionnaires, interview guides. Also, researchers intend to understand the social conditions in depth, discover patterns, hypotheses, and theories regarding Performance Management PE Primary School Teachers certified in Makassar. The data source was selected using purposive sampling. Informants were those who were involved directly in the conditions and events which can provide objective information on the performance management of PE elementary school teacher certified as certified teachers, principals, students and the public school environment.

\section{RESULTS}

The performance of PE Teachers has been good, as proven by the fact that PE teachers have made complete learning devices. The form of this devices annual program, the semester program, syllabus, lesson plan (RPP), a minimum completeness criteria (KKM) schedule face-to-face and other supporting devices with a blend of his creations, the internet, and Teacher Working Group. Also, PE certified teachers develop learning tools by considering aspects of psychomotor, affective and cognitive in moral action, movement skills and 
knowledge to think through physical activity and healthy living, that planning can achieve national education goals.

PE Teachers have to develop a device based curriculum syllabus contains a valid form of standard and basic competencies that aim to determine the standard of competence and basic competences (SK-KD) which are possible to be taught to the students in advance. Having determined SK-KD in the syllabus, teachers developed the lesson plan that includes indicators of achievement by pupils.

Certified PE teachers also have to developed indicators in line with the school environment, both the characteristics of students, facilities and adequate supporting facilities. Furthermore, in determining and developing learning materials, certified PE could support the achievement of basic competence by considering the characteristics of students includes physical, emotional and intellectual, as well as the condition of school facilities and infrastructure.

Certified PE Teachers select the source and medium of learning. It regards to SK-KD and learning objectives such as textbooks, the Internet and other supporting books with are the constraints of all schools is the lack of facilities and adequate infrastructure tools equipment and facilities. It also regards to the proportional of the number of pupils. So this is an obstacle in the process of learning, but the teacher can anticipate by utilizing the facilities and infrastructure outside of school. Further, tools that are not available in schools will be modified according to tool usability and utilization or teachers who use the LCD as the audio-visual media.

Certified PE of teachers can determine instructional methods contained in document RPP as a demonstration and lecture was done by providing examples of conducting systematic basic techniques and approaches such as lectures conducted briefly explain learning objectives. They also can argue that the distribution of the time is good because it fits the curriculum applicable $4 \times 35$ minutes in one lesson process and is considered good for the whole $\mathrm{KD}$ and indicators of achievement. The time was not quite certain of the subject matter as a solution to eliminate student teacher to play at recess.

Certified PE of teachers has conducted the preparation types and assessment techniques. They use the practices, and the written test refers to the learning objectives as a domain on psychomotor, affective, and cognitive. The completeness understands each basic competency through written test/quiz students after participating in learning.

Based on observations of researchers, Certified PE Teachers in learning implementation have been carrying out the task quite well, but still, most of the steps of learning are not maximized. After conducting interviews and observations implementation of learning elementary school of PE teachers in Makassar certified can be summed up, in general, have done pretty well but has not been maximized by the planning PE teachers conducting preliminary, are marching, praying, presence, motivation, prepare psychologically and physically and give examples briefly. PE Teachers do not implement the perception and explain the purpose of learning in core activities PE teacher presents the material includes the exploration and elaboration.
Teacher gives the exploration and elaboration briefly by using demonstrations and lectures are interactive such as how to perform exercise variations and combinations of the basic motion ball game great basketball in the way of dribbling the ball, pass the ball while in play small ball by hitting, catching and toss the ball. Further, implementing the regulation game simple to use source texts apply appropriate curriculum, and instructional media were modified among other courts, basketball, tennis ball, a whistle and a basketball hoop. The other things that have not performed optimally include classroom management does not involve the entire student and confirmation of events and activities, in the end, do not give feedback and conclude the lesson.

The results of interviews with the principal (Mr. BS) do not match with the results of interviews and documentation study of three PE teachers. It can be seen that the three PE teachers did not put together a program of follow-up in writing in the form of remedial and enrichment activities. Then the teachers do not implement programmatic follow-up program. Based on interviews and documentation study, researchers were able to conclude that the conduct of the evaluation or assessment conducted PE certified teacher is good.

\section{DISCUSSION}

Performance management of certified PE teacher in elementary school in Makassar can be seen from the lesson plan, the implementation of learning and evaluation. Stated aligned Podgursky \& Springer, the internal factor of teacher performance is a factor that comes from within themselves teachers that can affect their performance, for example, is personality; professional development; and the ability to teach [2].

Certified PE elementary school teachers in Makassar have good planning of learning which includes the preparation of learning tools, describing the learning objectives, select or determine the subject matter, determining teaching methods, determine the media or learning resources, assessment tools used and time allocation. The results of this study related to Ananda, Mukhadis, \& Andoko that the majority (78.77\%) of teachers who are certified have a good pedagogical [3]. It also related to the findings of Sikki, Rahman, Hamra, \& Noni that the teacher competence directly affects the learning achievement [4].

Certified PE elementary school teacher in the city of Makassar have carried out the implementation phases of learning is quite good but not maximized. Learning implementation includes open lessons, presenting the subject matter, method, use of the media, classroom management, summed up the lessons and provide feedback. It can be seen that when she starts learning PE teacher perception is not performed optimally because it did not stimulate the students to remember the previous material and did not explain the purpose of learning to the students. However, in the core activities of $\mathrm{PE}$ teachers in providing and mastering the material systematically using appropriate learning methods, $\mathrm{KD}$ can trigger motivation and student involvement as well as utilize a variety of sources and media to the maximum available at the school and classroom management is done with the active and orderly. 
However, in the concluding the lesson activities and provide follow-up at the end of activities, teachers did not carry out at all. This is not by the regulations of the Minister of National Education No. 41 of 2007 on the standard process for Primary and Secondary education units. The implementation of learning is the application of the RPP which includes the introduction, the core activities, and closing activity. Learning activities in the classroom are a core provision of education characterized by their classroom management activities, the use of media and learning resources [5], as well as the use of methods and learning strategies. All of it is the duty and responsibility of teachers in its implementation demands the ability of teachers optimally.

\section{CONCLUSION}

The results of research concluded that the performance of certified PE elementary school teacher in the city of Makassar in instructional planning has been good. The performance certified Physical Education elementary school teacher in the city of Makassar in the implementation of learning is quite good but not implemented systematically. The performance of certified Physical Education elementary school teacher in the city of Makassar in the evaluation of learning is good.

\section{REFERENCES}

[1] N. Ramdhani, D. Ancok, Y. Swasono, and P. Suryanto, 'Teacher Quality Improvement Program: Empowering Teachers to Increasing a Quality of Indonesian's Education', Procedia-Social Behav. Sci., vol. 69, pp. 18361841, 2012.

[2] M. J. Podgursky and M. G. Springer, 'Teacher performance pay: A review', J. Policy Anal. Manag., vol. 26, no. 4, pp. 909-949, 2007.

[3] A. F. Ananda, A. Mukhadis, and A. Andoko, 'Kinerja Guru Kejuruan Bersertifikat Pendidik ditinjau dari Standar Kompetensi Guru Profesional sesuai Undang-Undang Nomor 14 Tahun 2005', Teknol. dan Kejuru., vol. 33, no. 1, 2012.

[4] E. A. A. Sikki, A. Rahman, A. Hamra, and N. Noni, 'The competence of primary school English teachers in Indonesia', J. Educ. Pract., vol. 4, no. 11, pp. 139-145, 2013.

[5] A. Bandur, 'School-based management developments and partnership: Evidence from Indonesia', Int. J. Educ. Dev., vol. 32, no. 2, pp. 316328, 2012. 